\title{
Graphene oxide as a protein matrix: influence on protein biophysical properties
}

Griselle Hernández-Cancel, Dámaris Suazo-Dávila, Axel J. Ojeda-Cruzado, Desiree García-Torres, Carlos R. Cabrera and Kai Griebenow*

\begin{abstract}
Background: This study provides fundamental information on the influence of graphene oxide (GO) nanosheets and glycans on protein catalytic activity, dynamics, and thermal stability. We provide evidence of protein stabilization by glycans and how this strategy could be implemented when GO nanosheets is used as protein immobilization matrix. A series of bioconjugates was constructed using two different strategies: adsorbing or covalently attaching native and glycosylated bilirubin oxidase (BOD) to GO.
\end{abstract}

Results: Bioconjugate formation was followed by FT-IR, zeta-potential, and X-ray photoelectron spectroscopy measurements. Enzyme kinetic parameters $\left(k_{m}\right.$ and $\left.k_{\text {cat }}\right)$ revealed that the substrate binding affinity was not affected by glycosylation and immobilization on GO, but the rate of enzyme catalysis was reduced. Structural analysis by circular dichroism showed that glycosylation did not affect the tertiary or the secondary structure of BOD. However, GO produced slight changes in the secondary structure. To shed light into the biophysical consequence of protein glycosylation and protein immobilization on GO nanosheets, we studied structural protein dynamical changes by FT-IR H/D exchange and thermal inactivation.

Conclusions: It was found that glycosylation caused a reduction in structural dynamics that resulted in an increase in thermostability and a decrease in the catalytic activity for both, glycoconjugate and immobilized enzyme. These results establish the usefulness of chemical glycosylation to modulate protein structural dynamics and stability to develop a more stable GO-protein matrix.

Keywords: Bilirubin oxidase, Graphene oxide, Glycosylation, Structural protein dynamic, Thermostability

\section{Background}

Understanding the effect of nanomaterials on protein functional and biophysical properties is of fundamental importance in the area of bio-nanotechnology. Enzymes are protein molecules involved in all processes essential for life, but their function depends on the integrity of their secondary and tertiary structure. Unfortunately enzymes can undergo conformational changes due to interference or disruption of the non-covalent interactions stabilizing them (electrostatic interactions, hydrogen bonds, and van der Waals forces). Furthermore, the structural dynamics of protein molecules is a significant component that regulates the proper catalytic function,

*Correspondence: kai.griebenow@gmail.com

Department of Chemistry, University of Puerto Rico, Río Piedras Campus, San Juan, PR 00931, USA which until now has largely not been considered during the discussion of the effect of nanomaterials on proteins. Previous studies usually correlate the loss in catalytic activity with changes in the protein structure [1-3], however here we provide evidence that protein dynamics is affected when the enzyme is covalently attached to graphene oxide (GO) nanosheets. Substrate recognition requires protein flexibility because it facilitates conformational rearrangements at the substrate-binding region $[4,5]$. Hence, any change in protein dynamics caused by the nanomaterial will affect protein catalytic activity. The influence of structural dynamics on enzyme kinetics has been studied in detail in our laboratory [6-8].

GO has been used as a matrix for enzyme immobilization in different biotechnological applications, such as biosensors [9, 10], biofuel cells [11], cellular imaging 
[12], gene and drug delivery [13, 14], among others [1517]. Therefore, the influence of GO on protein structure and its function should be addressed to obtain information that is pertinent across multiple disciplines. In addition to the fundamental information, it is imperative to implement protein stabilization strategies during the immobilization procedure in order to extend the final product shelf life. GO sheets provide large surface areas with surface oxygen-containing groups which have been functionalized with polyethylene glycol (PEG) [18], monolayers of the $N$-hydroxysuccinimidyl ester tripod (NHStripod) [19], cationized bovine serum albumin (cBSA) [1], and concanavalin A (Con A) [20] to improve the structure, activity, and stability of enzymes. Herein, we explore the concept of protein engineering through the attachment of polysaccharide chains, also known as glycans, to the $\varepsilon$-amino group of lysine residues. This strategy has been used previously by our group and other researchers to enhance the stability of proteins in pharmaceutical formulations, biosensors, and others biotechnological applications [7, 8, 21-26]. Chemical glycosylation of proteins has proven to be an excellent alternative to modulate protein properties; hence, we are seeking to extend those findings to applications based on carbon nanomaterials.

Several studies have investigated the potential effect of GO on proteins, such as, glucose oxidase (GOD) [1, 27], horseradish peroxidase (HRP) [1-3], oxalate oxidase $(\mathrm{OxOx})[2]$, lysozyme [1, 3], cytochrome c (Cyt C) [1], catalase [1], bovine serum albumin (BSA) [1], chymotrypsin [18], trypsin [18], and proteinase K [18]. Zang et al. found that HRP and lysozyme were immobilized on GO sheets through electrostatic interactions if the $\mathrm{pH}$ level was below the isoelectric point (pI), but if the $\mathrm{pH}$ level was above the $\mathrm{pI}$ they suggested that hydrogen bonds interaction prevailed [28]. In a subsequent publication, they performed different reduction degrees of GO and showed that above the enzyme's pI, hydrophobic interactions were responsible for enzyme loading [2]. They also found that when the phosphate buffer concentration (ionic strength) increased from 10 to $100 \mathrm{mM}$ the amount of immobilized enzyme increased.

In the present work we investigated the effect of $\mathrm{GO}$ nanosheets on BOD catalytic activity, structure, dynamics, and thermal stability (Fig. 1). BOD is a multi-copper oxidase that has been used in several biotechnological applications, such as, biosensors [29, 30], biofuel cells [31-33], and other environmental and industrial applications [34, 35]. Due to the wide range of biotechnological applications, BOD was selected as our model enzyme. This is the first time that BOD was chemically glycosylated and the effect on protein structural dynamics caused by graphene oxide nanosheets was investigated. We show that compared to native BOD, glycosylation

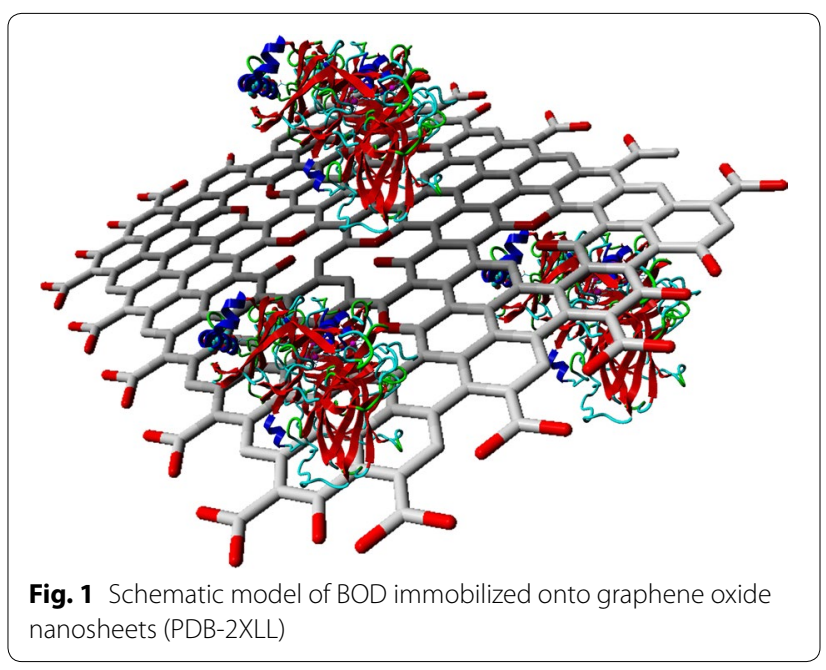

of BOD produced a decrease in the structural dynamics while the thermostability increased. Likewise, when the glycosylated BOD was immobilized on GO nanosheets, the decrease in structural dynamics and the increase in thermostability were even more pronounced. These data demonstrate the potential application of chemically glycosylated proteins to produce highly stable biofunctionalized GO nanosheets for bio-nanotechnology applications.

\section{Results and discussion}

Despite the progress made in materials science combined with biotechnology, there still is a lack of fundamental knowledge regarding the effect of nanomaterials, such as graphene oxide, on biophysical protein properties. Also, the potential applications of enzymes within a manifold of bio- and nanotechnological areas have been hampered by stability issues and remain a critical factor that has to be overcome. Herein, we performed a comprehensive study on how protein biophysical properties (e.g., function, structure, dynamics, and thermostability) were affected as the result of the immobilization process. We also explore the possibility to chemically glycosylate the enzyme to retain protein stability without losing its functionality.

\section{Characterization of BOD-GO bioconjugates}

The enzyme immobilization in GO was carried out as described in the experimental section. The enzyme loading was determined from the supernatant. The estimated concentration of immobilized protein, both, adsorbed or covalently attached to $\mathrm{GO}$, was $0.2 \mathrm{mg} \mathrm{mL}^{-1}$. Zhang et al. showed that when reducing the oxidation degree of GO the loading of the HRP increases from 0.1 to $1.31 \mathrm{mg} \mathrm{mL}^{-1}[2]$. This result suggests that our GO is 
not fully oxidized due to the amount of enzyme that was immobilized on the GO nanosheets. Refer to the supporting information (Additional file 1) for more detail about the synthesis and characterization of GO. The zeta-potential can provide additional evidence of the formation of the BOD-GO bioconjugates (Table 1). GO in $0.1 \mathrm{M}$ PBS pH 7.4 solution shows a zeta-potential of $-23 \pm 1 \mathrm{mV}$ in agreement with previously reported potentials at $\sim \mathrm{pH} 7$ [27]. According to the manufacturer, the isoelectric point of BOD is 4.1, which implies that under the experimental conditions BOD exists as a polyanion. Native BOD in $0.1 \mathrm{M}$ PBS pH 7.4 at a concentration of $0.2 \mathrm{mg} \mathrm{mL}^{-1}$ shows a zeta-potential of $-6 \pm 1 \mathrm{mV}$. After the immobilization a positive shift of approximately $8 \mathrm{mV}$ was observed, indicating that a considerable change in the surface charge of GO occurred due to the enzyme immobilization.

X-ray photoelectron spectroscopy (XPS) was used to verify the activation of GO with sulfo-NHS and the immobilization of BOD on GO. The appearance of an S $2 \mathrm{p}_{1 / 2}$ binding energy signal at $168 \mathrm{eV}$ corresponding to the sulfite anion indicates the formation of the reactive intermediate upon activation of the GO with sulfo-NHS (Fig. 2b). As expected, the sulfite anion signal disappears upon enzyme immobilization suggesting the formation of a covalent bond between GO and BOD. The only binding energy peak that remained corresponds to the single cysteine residue in BOD at $163 \mathrm{eV}$ (Fig. 2b) [36]. This peak $(163 \mathrm{eV})$ was also observed in the BOD-GO-A bioconjugate indicating the presence of the protein in GO. The XPS high-resolution spectra of $\mathrm{N}_{1} 1 \mathrm{~s}_{1 / 2}$ were used to corroborate the EDC/sulfo-NHS intermediate and the presence of the immobilized protein on GO (Fig. 2b). We observed the presence of two different $\mathrm{N}$ atom populations; one at $400 \mathrm{eV}$ attributed to the protonated amine of EDC and the second at $403 \mathrm{eV}$ indicating the presence of the nitrogen of the sulfo-NHS in accordance with previously reported data [22]. An intense $\mathrm{N}$ binding energy peak at $398 \mathrm{eV}$ corresponding to the $\mathrm{N} 1 \mathrm{~s}_{1 / 2}$ orbital was

Table 1 Zeta-potential values of graphene oxide after the oxidation process, native and glycosylated BOD, and bioconjugate formation

\begin{tabular}{lcc}
\hline Sample & Solvent & Z potential \\
\hline GO & 0.1 M PBS pH 7.4 & $-23 \pm 1$ \\
BOD & & $-6 \pm 1$ \\
Dex-BOD & & $-4 \pm 0.9$ \\
BOD-GO-A & $-16 \pm 1$ \\
BOD-GO-C & $-15.5 \pm 0.8$ \\
Dex-BOD-GO-C & $-13.6 \pm 0.6$ \\
\hline
\end{tabular}
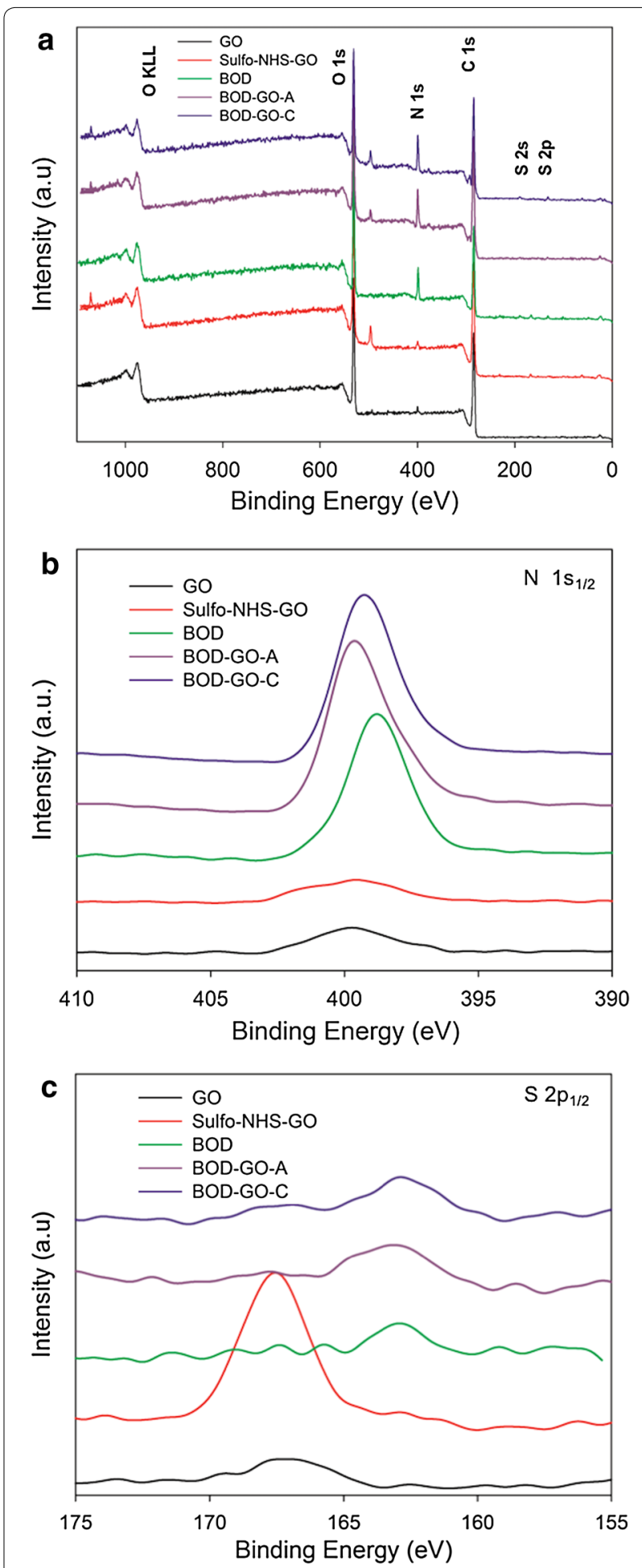

Fig. 2 X-ray photoelectron spectroscopy binding energy survey (a) and high resolution spectra of $\mathrm{N} 1 \mathrm{~s}_{1 / 2}$ (b) and $\mathrm{S}_{2} \mathrm{p}_{1 / 2}$ (c) binding energy region for GO, sulfo-NHS-GO, BOD, BOD-GO-A, and BOD-GOC. All spectra were background corrected and vertically displaced for ease of visualization 
observed in the high-resolution spectra of the protein (Fig. 2a). After the immobilization, the nitrogen peak of the protein shifted slightly to higher binding energies $(401 \mathrm{eV})$ indicating a change on the environment of the protein as a result of the interaction with GO. In conclusion, the XPS data confirmed the individual bioconjugate construction steps.

From the FT-IR spectra we also determined the presence of BOD in GO. Figure 3a shows the characteristic FT-IR spectrum of GO. The amide I mode $\left(1640 \mathrm{~cm}^{-1}\right)$ largely corresponds to the $\mathrm{C}=\mathrm{O}$ stretching vibration and the amide II $\left(1530 \mathrm{~cm}^{-1}\right)$ mode has $\mathrm{N}-\mathrm{H}$ bending and $\mathrm{C}-\mathrm{N}$ stretching vibration contributions (Fig. 3c) demonstrating the successful immobilization of BOD in GO. It is interesting to note that the peak that corresponds to carboxylic acid groups $(\mathrm{C}=\mathrm{O})$ at $1720 \mathrm{~cm}^{-1}$ disappears as a result of this immobilization, confirming the coupling of BOD in GO.

\section{Chemical glycosylation of bilirubin oxidase}

Chemical glycosylation is a useful approach to modulate protein structural dynamics without altering the amino acid composition, thus allowing the study of its impact on the fundamental biophysical properties [7]. Another benefit of protein glycosylation is the increase in protein stability, which results in a more robust protein that can better resist denaturing conditions encountered during the production of biotechnological devices and pharmaceutical formulations, extending the useful life of the final product. To form the glycolconjugate we attached dextran $(1 \mathrm{kDa})$ by suitable linker chemistry to the lysine and amino-terminal groups of BOD, which has 11 solvent accessible amino residues. First, dextran

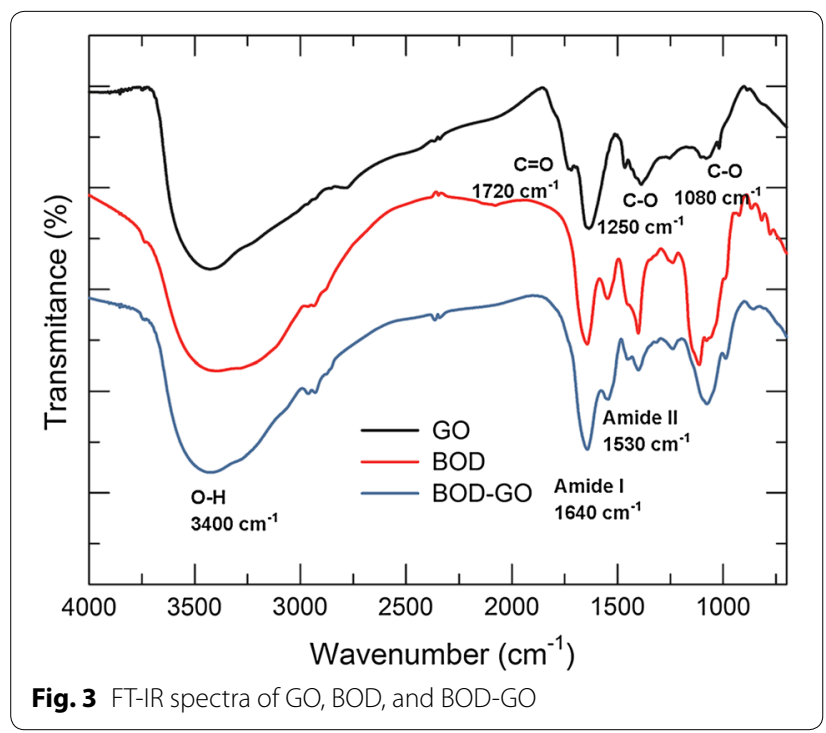

hexanoic acid was activated to form sulfo-NHS-Dex (Fig. 4a). Then, the sulfo-succinimidyl group was used us to couple the glycan to the protein (Fig. 4b). XPS was used to confirm dextran activation. Figure $5 \mathrm{a}$, b shows the XPS high-resolution spectra of $\mathrm{N} 1 \mathrm{~s}_{1 / 2}$ and $\mathrm{S} 2 \mathrm{p}_{1 / 2}$ binding energy regions, respectively. The results demonstrate two different $\mathrm{N}$ species that correspond to EDC/Sulfo-NHS with an intense peak at 399 and $401 \mathrm{eV}$ (Fig. 5a). The XPS peak at $166 \mathrm{eV}$ corresponding to the sulfur atom $\left(\mathrm{S} 2 \mathrm{p}_{1 / 2}\right)$ indicates the sulfo-NHS-Dex formation.

The TNBSA method was used to determine the amount of covalently attached dextran [37]. Our results demonstrate that $5.7 \pm 0.5$ lysine residues of BOD were glycosylated and the conjugate is thus referred to as DexBOD. To examine if the glycosylation process produces a shielding effect, hence decreasing the formal charge of the protein, we performed a zeta-potential analysis. Table 1 shows the average zeta-potential of the native $(6 \pm 1 \mathrm{mV})$ and the glycosylated BOD $(4.9 \pm 0.9 \mathrm{mV})$ in $0.1 \mathrm{M} \mathrm{PBS} \mathrm{pH} 7.4$ at $25^{\circ} \mathrm{C}$. These results show a decrease in the formal charge of the protein upon glycosylation due to the attachment of the glycan to the protein surface.

\section{Specific activity and kinetic parameters}

Lyophilization is a common procedure used to formulate proteins for long-term storage. It is well know that protein stability during freeze-drying is affected due to stresses that arise from the low temperature, formation of ice, and dehydration [38]. For this reason we decided to study how this step during sample preparation would affect specific activity of native BOD, denoted as LyoBOD (Table 2). The Lyo-BOD was dissolved in water, frozen in liquid $\mathrm{N}_{2}$, and lyophilized for $48 \mathrm{~h}$, then reconstituted with $0.1 \mathrm{M}$ PBS $\mathrm{pH}$ 7.4. We found that the catalytic properties of Lyo-BOD and Dex-BOD decreased significantly while immobilized BOD-GO-A and BODGO-C remained highly active. But in comparison with the adsorbed bioconjugate, the BOD-GO-C showed a decrease in the catalytic activity, implying that covalent binding in some way affects the catalytic performance of this bioconjugate. Although the catalytic activity was affected, the $K_{m}$ values of the samples remained essentially the same, indicating that they all had a similar substrate affinity.

The catalytic activity of covalent bioconjugate (BODGO-C), in comparison to BOD-GO-A, was significantly affected. Therefore, we decided to examine if chemical glycosylating could enhance the performance of immobilized BOD the resulted covalent bioconjugate. We observed that Dex-BOD-GO-C also showed a decrease in the specific activity that was not caused by 


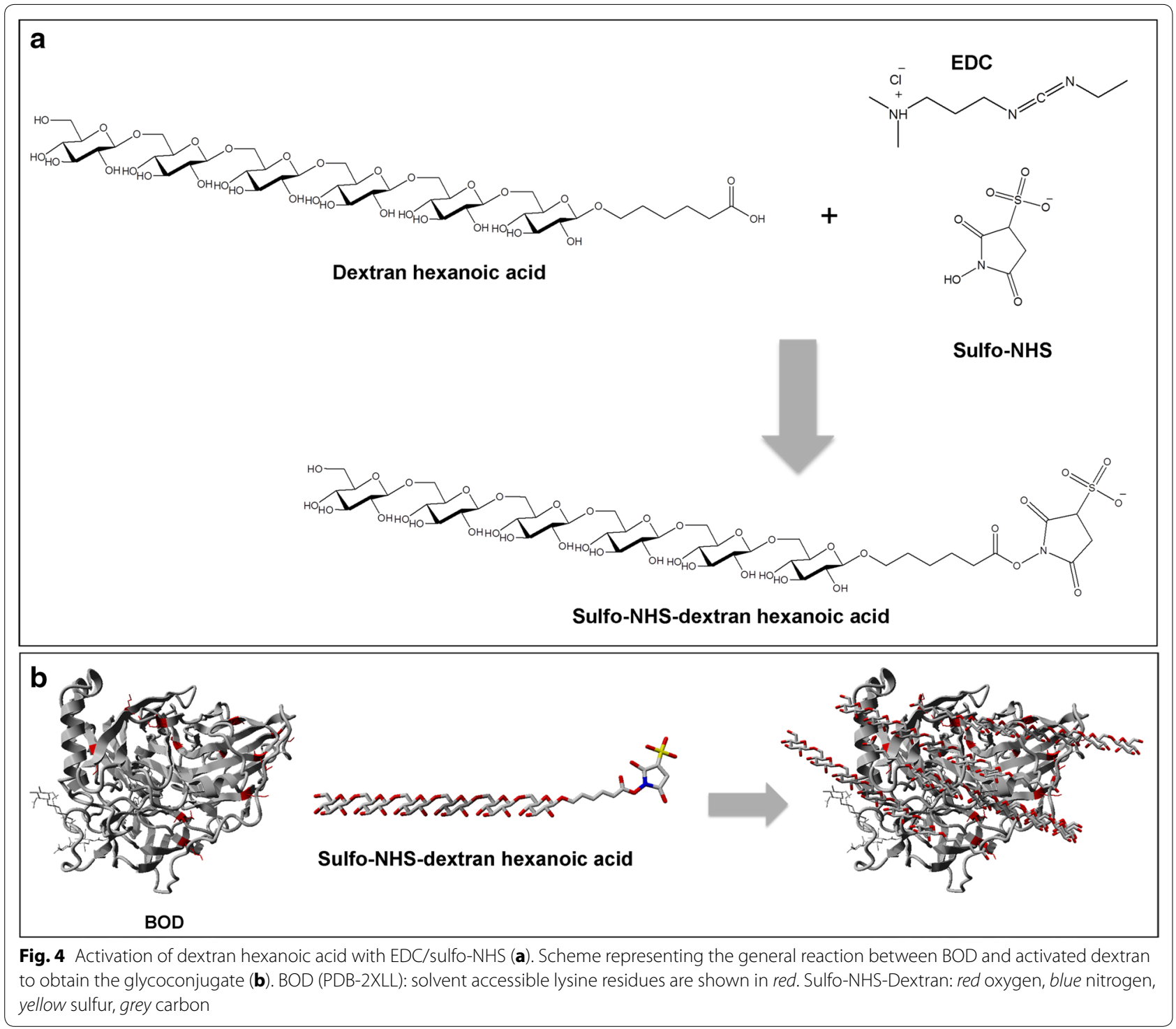

the immobilization, rather by the glycosylation process. We also found a reduction in the turnover rate $\left(k_{\text {cat }}\right)$ for the Lyo-BOD, Dex-BOD, and therefore Dex-BOD-GO-C. Although the decrease in $k_{c a t}$ value was more significant for the previous samples, there was a minimal change in the adsorbed and covalent bioconjugates. These results suggest that GO does not have a significant influence on the catalytic activity of the glycosylated enzyme. However, the lyophilization and glycosylation process caused a reduction in catalytic efficiency $\left(K_{m} k_{c a t}^{-1}\right)$ of the protein in comparison with that of the native BOD. Proteins are dynamical systems and their catalytic activity requires a balance between flexibility and stability. Enzymes must be stable enough to retain their native tertiary structure, but dynamic enough to perform the substrate binding and the subsequent product release $[8,39]$. Previous research has shown that protein dynamics are affected by the glycosylation process [7]. To further understand if the catalytic activity reduction was caused by changes in protein structure we performed CD spectroscopy.

\section{Structural analysis by $\mathrm{CD}$ spectroscopy}

The CD spectra of proteins are dependent on their conformation; therefore, it is an excellent method to monitor conformational changes due to chemical glycosylation or binding interactions with nanomaterials. To assess the effect of the lyophilization and glycosylation process on the tertiary protein structure, we collected the $\mathrm{CD}$ spectra in the near-UV region (Fig. 6a). The spectrum of native BOD had six maxima between 250 and $300 \mathrm{~nm}$ that result from the environment of aromatic amino acids Phe, Tyr, and Trp [36]. The CD spectra of 


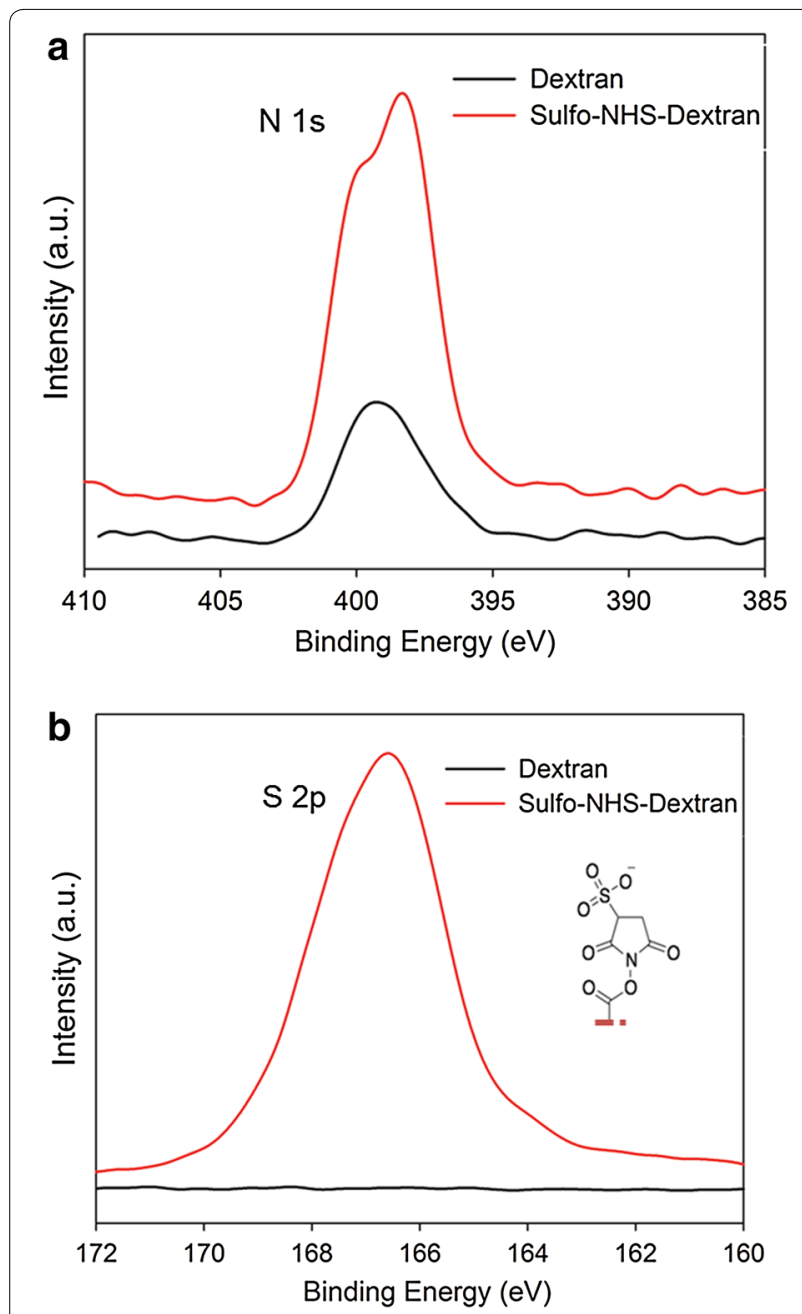

Fig. 5 High-resolution $X$-ray photoelectron spectroscopy of $N 1 s_{1 / 2}$ (a) and $\mathrm{S} 2 \mathrm{p}_{1 / 2}$ (b) binding energy region acquired from dextran and dextran activated with sulfo-NHS. All spectra were background corrected and vertically displaced for ease of visualization

Table 2 Comparison of catalytic parameters derived from the oxidation of ABTS by BOD

\begin{tabular}{llllr}
\hline & $\begin{array}{l}\text { Specific activity } \\
\left(\mathbf{U ~ m g}^{-1}\right)\end{array}$ & $\boldsymbol{K}_{\boldsymbol{m}}(\mathbf{m M})$ & $\boldsymbol{k}_{\text {cat }}\left(\mathbf{s}^{-\mathbf{1}}\right)$ & $\boldsymbol{k}_{\text {cat }} / \mathbf{K}_{\mathbf{m}}$ \\
\hline BOD & $3618 \pm 28$ & $29.1 \pm 0.6$ & $385 \pm 18$ & $13.2 \pm 0.5$ \\
Dex-BOD & $1841 \pm 25$ & $26.8 \pm 0.6$ & $171 \pm 10$ & $6.4 \pm 0.3$ \\
Lyo-BOD & $1908 \pm 23$ & $25.2 \pm 0.5$ & $195 \pm 11$ & $7.8 \pm 0.6$ \\
BOD-GO-A & $3302 \pm 29$ & $30.2 \pm 0.6$ & $325 \pm 23$ & $10.7 \pm 0.7$ \\
BOD-GO-C & $2435 \pm 28$ & $27.8 \pm 0.9$ & $230 \pm 12$ & $8.3 \pm 0.5$ \\
Dex-BOD-GO-C & $1321 \pm 27$ & $28.4 \pm 0.5$ & $137 \pm 8$ & $4.8 \pm 0.1$ \\
\hline
\end{tabular}
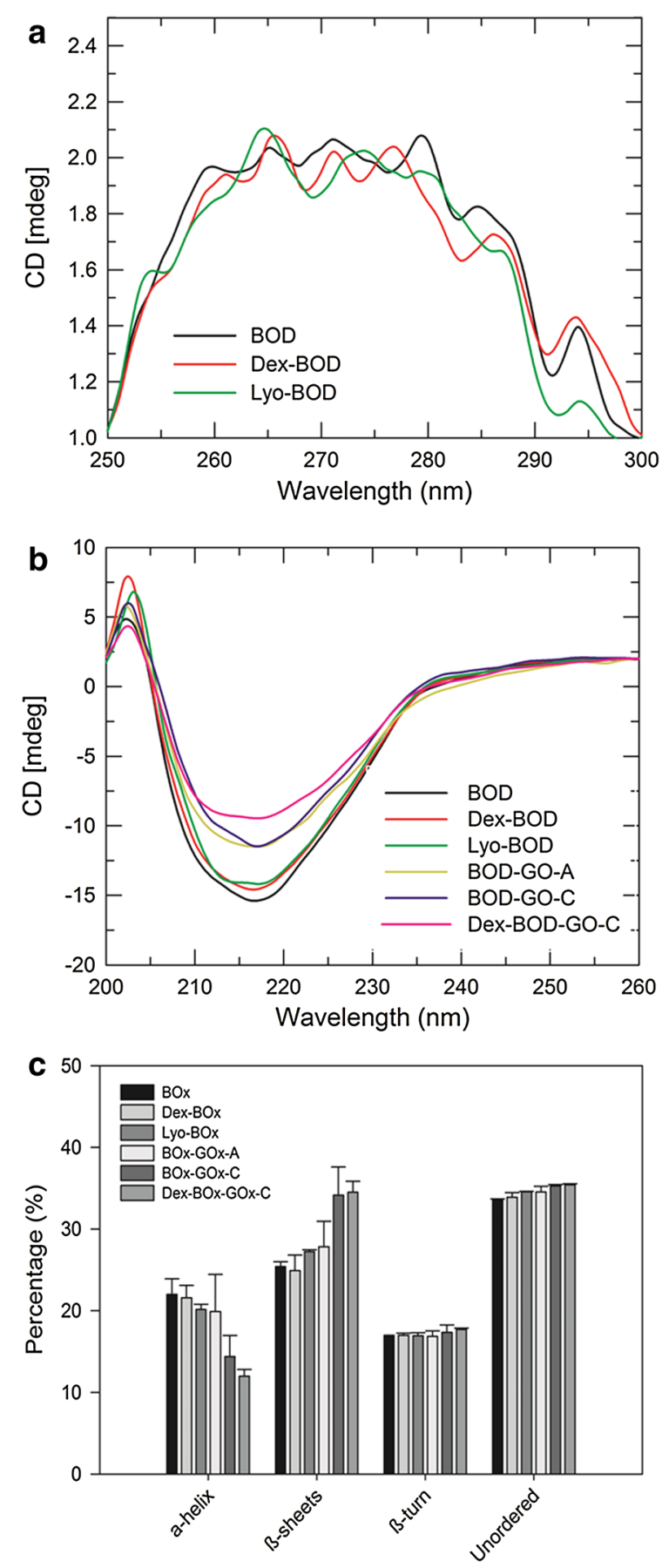

Fig. 6 Near-UV CD spectra of BOD, Dex-BOD, Lyo-BOD in 0.1 M PBS $\mathrm{pH} 7.4$ at $25^{\circ} \mathrm{C}(\mathbf{a})$. Far-UV CD spectra of BOD, Dex-BOD, Lyo-BOD, BOD-GO-A, BOD-GO-C, and Dex-BOD-GO-C in $0.1 \mathrm{M}$ PBS pH 7.4 at $25^{\circ} \mathrm{C}(\mathbf{b})$. Estimates of the secondary structure calculated from the $\mathrm{CD}$ spectra using CDNN program $(\mathbf{c})$. The data represented here was obtained by averaging three independent measurements $(n=3)$.

The error bar represents the standard deviation 
BOD, Dex-BOD, and Lyo-BOD were quite similar. In the far UV-region, BOD showed a negative CD band at $218 \mathrm{~nm}$ and a positive band at $205 \mathrm{~nm}$, indicating the predominance of the $\beta$-structure (Fig. 6b) [40]. The intensities of the positive band in BOD-GO-A, BOD-GO-C, and Dex-BOD-GO were found to increase whereas the negative band decreased, in comparison with that of the native BOD. These results suggest a minimum change in the secondary structure of the BOD as a consequence of the interaction with GO. The CD spectra in the far UV region were analyzed using the $\mathrm{CDNN}$ program to obtain information about the secondary structural composition (Fig. 6c). These results indicate that the native conformation of BOD contains $\sim 20 \% \alpha$-helix, $\sim 28 \%$ of $\beta$-sheets, $\sim 17 \% \beta$-turns and $\sim 35 \%$ of unordered structure, in agreement with previously reported data [36]. After the immobilization with GO, the amount of $\alpha$-helix structure decreases and the amount of $\beta$-sheets increases, while the percentage of $\beta$-turns and unordered structure almost remains constant. These changes in the secondary structure as a result of the interaction with the GO may contribute to the loss in the catalytic activity of the protein. In contrast, the secondary structure of the chemically glycosylated BOD remained very similar to the native protein, suggesting that glycosylation helps stabilize protein structure.

\section{Protein structural dynamics: H/D exchange}

Amide I (1600-1700 $\mathrm{cm}^{-1}$ ) region in protein spectra largely arise from $\mathrm{C}=\mathrm{O}$ stretching vibration with a minor contribution from the $\mathrm{C}-\mathrm{N}$ stretching vibrations and amide II $\left(1500-1600 \mathrm{~cm}^{-1}\right)$ largely results from $\mathrm{N}-\mathrm{H}$ bending and $\mathrm{C}-\mathrm{N}$ stretching vibrations [41]. Upon exposure to $\mathrm{D}_{2} \mathrm{O}$, the amide II band shifts to lower wavenumbers $\left(1400-1500 \mathrm{~cm}^{-1}\right)$ as a result of the exchange with deuterium. Observing the decay of amide II intensity scaled by amide I intensity allows studying the protein dynamics as a consequence of glycosylation and immobilization on GO. The initial exchange rate is very fast since there are solvent exposed amide bonds. However, the amide bonds that are inaccessible to the solvent will exchange at a much slower rate. Therefore, the exchange rates of amide hydrogens that are less accessible or buried inside the native protein, provide a method for monitoring protein conformational changes and dynamical processes [42].

Figure 7a shows the spectroscopic results from a typical FT-IR H/D exchange experiment for BOD, where the unexchanged amide groups $(\mathrm{N}-\mathrm{H})$ decreased while the exchanged ones (N-D) increased over time [43]. To examine the relationship between protein structural dynamics and amide hydrogen exchange, we plotted the fraction $\mathrm{X}$ of unexchanged amide groups over time (Fig. 7b).
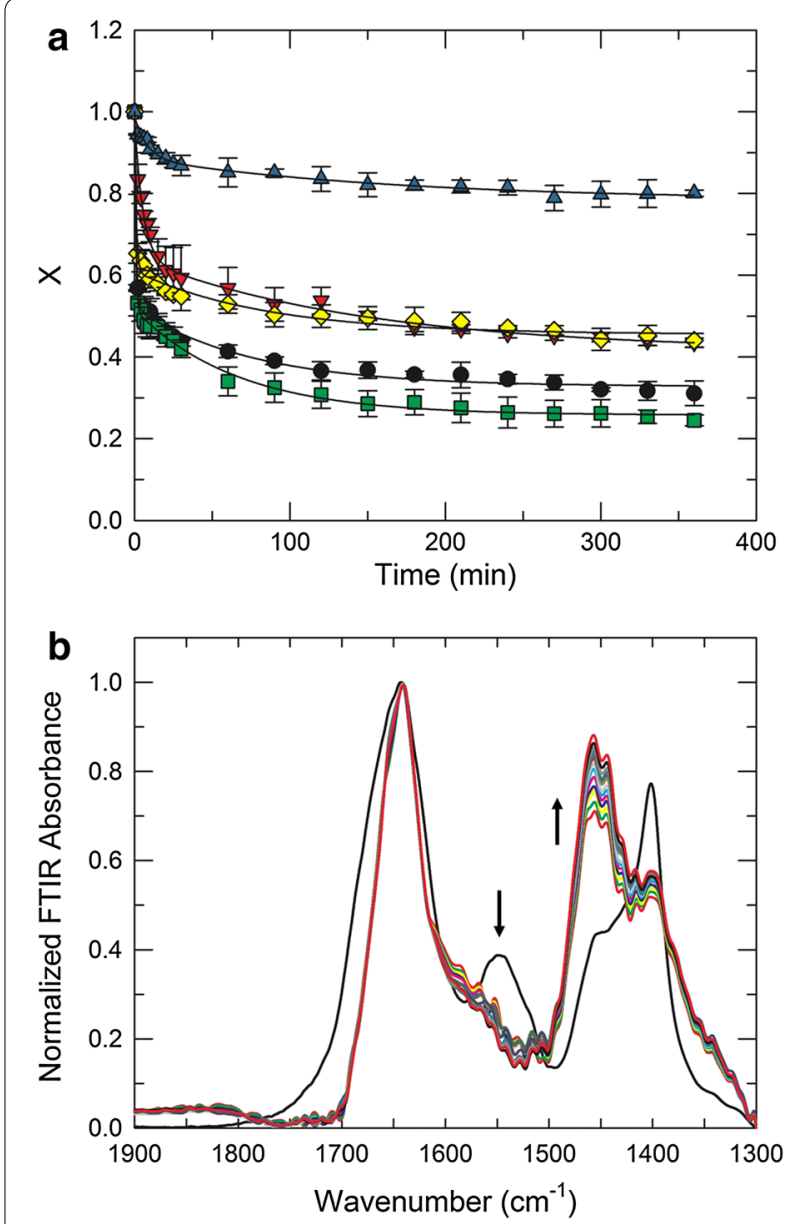

Fig. 7 A typical FTIR-H/D exchange experiment for BOD, arrows highlight both the decreasing amide II band $\left(\mathrm{N}-\mathrm{H} ; 1550 \mathrm{~cm}^{-1}\right)$ and the increasing amide II'band $\left(\mathrm{N}-\mathrm{D} ; 1450 \mathrm{~cm}^{-1}\right)$. a H/D exchange decay plots at $25^{\circ} \mathrm{C}$ ( $\mathrm{pD}$ 8.2) for BOD (filled circle), Dex-BOD (filled inverted triangle), BOD-GO-A (filled square), BOD-GO-C (filled diamond) and Dex-BOD-GO-C (filled triangle) (b)

Quantitative analysis of the decay plots was done with a bi-exponential model: [7, 43]

$$
X=A_{1} \exp ^{\left(-k_{H X, 1}\right) t}+A_{2} \exp ^{\left(-k_{H X, 2}\right) t}+A_{3}
$$

where $A_{1}, A_{2}$, and $A_{3}$ are the fraction of the fast, slow and stable amide groups and $\mathrm{k}_{\mathrm{HX}, 1}$ and $\mathrm{k}_{\mathrm{HX}, 2}$ are the apparent exchange rate constants (Table 3 ). The decay data reveal that upon chemical glycosylation both, Dex-BOD and Dex-BOD-GO-C, showed a decreased in population $\left(\mathrm{A}_{1}\right.$, $\left.\mathrm{A}_{2}\right)$ and rate constant $\left(\mathrm{k}_{\mathrm{HX}, 1}, \mathrm{k}_{\mathrm{HX}, 2}\right)$ that correspond to the fast and slow exchanging amide groups, with an increase in the population of stable amide groups $\left(\mathrm{A}_{3}\right)$. The observed stabilization of the enzyme conformation by protein glycosylation is consistent with other studies previously reported $[7,8]$. We also found that the adsorbed bioconjugates (BOD-GO-A) exhibited a similar behavior 
Table 3 Kinetic parameter derived from the H/D kinetic analysis

\begin{tabular}{llllllrl}
\hline & $\mathbf{A}_{\mathbf{1}}$ & $\boldsymbol{K}_{\mathbf{H X}, \mathbf{1}}\left(\mathbf{m i n}^{\mathbf{- 1}}\right)$ & $\mathbf{A}_{\mathbf{2}}$ & $\boldsymbol{K}_{\mathbf{H X} \mathbf{2}}\left(\mathbf{m i n}^{-\mathbf{1}}\right)$ & $\mathbf{A}_{\mathbf{3}}$ & $\boldsymbol{\Delta} \mathbf{G}^{\mathbf{m i c}}\left(\mathbf{K c a l ~} \mathbf{~ m o l}^{\mathbf{- 1}}\right)$ & $\left(\boldsymbol{\Delta} \mathbf{G}^{\mathbf{m i c}}\right)^{-\mathbf{1}}\left(\mathbf{K c a l}^{\mathbf{- 1}} \mathbf{~ m o l}\right)$ \\
\hline BOD & 0.479 & 1.062 & 0.192 & 0.0132 & 0.328 & 6.8 & 0.1472 \\
Dex-BOD & 0.336 & 0.1857 & 0.228 & 0.0067 & 0.415 & 940.1 & 0.0011 \\
BOD-GO-A & 0.483 & 1.049 & 0.259 & 0.0152 & 0.258 & 12.4 & 0.0805 \\
BOD-GO-C & 0.389 & 0.9721 & 0.155 & 0.0117 & 0.455 & 54.9 & 0.0182 \\
Dex-BOD-GO-C & 0.101 & 0.1257 & 0.104 & 0.006 & 0.783 & 1145.7 & 0.0009 \\
\hline
\end{tabular}

when compared to the native protein, however a decrease in both rate constants (fast and slow) was obtained from the covalent bioconjugates (BOD-GO-C). These results suggest that the covalent immobilization of BOD in GO produced a reduction in protein dynamics by virtue of the covalent bond, while the adsorbed protein had a more dynamical structure. The confinement produced by GO can also modulate the biophysical and structural features of proteins [44]. This confinement can also be found inside the cell, where chaperonins produce a "cage effect" to facilitating protein folding, thereby helping them to reach their functional conformation [45]. Several computational studies have also shown that this "cage effect" produced protein stability and this stabilization increased with increasing confinement [44-46].

The microscopic global free energy $\left(\Delta G^{\text {mic }}\right)$ was calculated to gather information about which state was more favorable and its inverse $\left(\Delta G^{\text {mic }}\right)^{-1}$ to know how protein mobility was affected. A substantial increase in $\Delta G^{\text {mic }}$ and a decrease in $\left(\Delta G^{\text {mic }}\right)^{-1}$ were obtained from Dex-BOD and Dex-BOD-GO bioconjugates. This result indicates that the folded state of the protein was more favorable and protein mobility decreased due to an increase in protein stability conferred by the glycan attached to the protein. Studies have been shown that confinement enhances the stability due to the decrease in the entropy of the unfolded state and increases the stability of the native structure $[44,46]$. The BOD-GOA shows a slight increase in $\Delta \mathrm{G}^{\text {mic }}$ for BOD-GO-C and a decrease in $\left(\Delta \mathrm{G}^{\mathrm{mic}}\right)^{-1}$. In conclusion, the reduction in protein dynamics mostly depends on the chemical glycosylation of the protein, but also has a contribution that arises from the confinement produced by the immobilization on GO. These results shed some light on the reasons for the loss of specific activity that was obtained for Dex-BOD and Dex-BOD-GO-C, demonstrating that the activity loss is related to a decrease in protein dynamics and not due to protein unfolding.

\section{Thermal inactivation}

In order to understand the influence of glycosylation and GO on protein thermostability we measured the enzyme kinetics as a function of time at $45^{\circ} \mathrm{C}$ (Fig. 8). The thermal inactivation process can be fitted using an

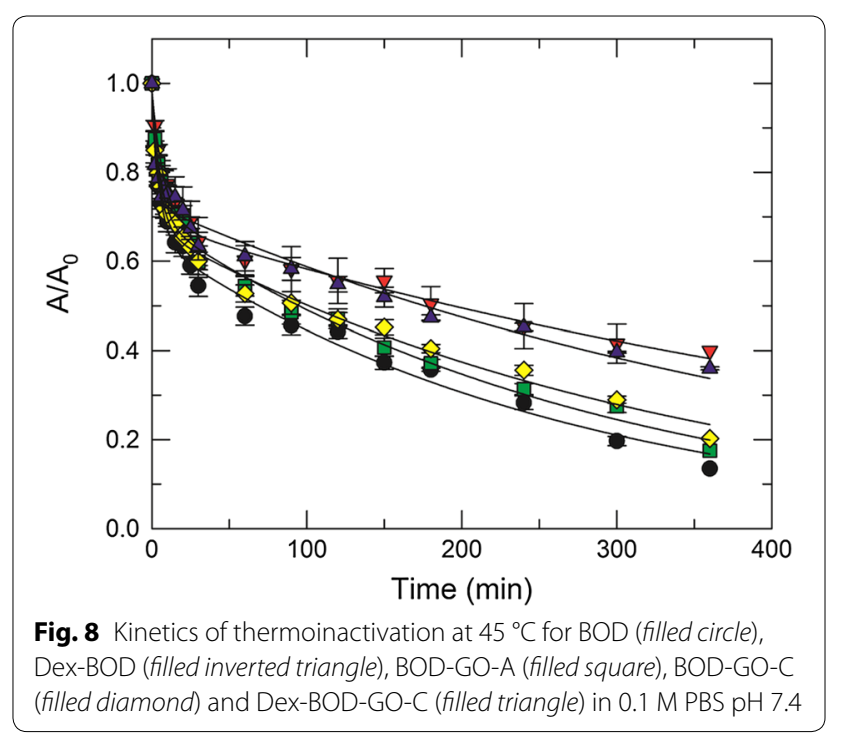

exponential decay model that consists of two kinetic rate constants; $k_{1}$ (fast) and $k_{2}$ (slow). These inactivation processes are described by the following equation: [7]

$$
A / A_{0}=\alpha_{1} \exp ^{\left(-k_{1} t\right)}+\alpha_{2} \exp ^{\left(-k_{2} t\right)}
$$

where $\mathrm{A} / \mathrm{A}_{0}$ is the relative enzymatic activity and $\alpha_{\mathrm{i}}$ and $\mathrm{k}_{\mathrm{i}}$ represent the populations and the rate constants for the two inactivation processes. We found that glycosylation reduced both kinetic constants $\left(k_{1}\right.$ and $\left.k_{2}\right)$ and increased the half-life $\left(t_{1 / 2}\right)$ for the fast and slow inactivation processes in Dex-BOD and Dex-BOD-GO-C (Table 4). It has been shown that glycosylation reduces the protein solvent accessible surface area by sterically shielding the surface of the protein [47]. This shielding produces an increase the internal non-covalent binding forces and simultaneously leads to a decrease in protein structural dynamics, thereby increasing the protein thermodynamic stability [47]. BOD-GO-C showed a similar behavior, but not as notable as glycosylated samples. These results confirmed that glycosylation produced a significant increase in the functional half-life of the glycoconjugate and glyco-bioconjugate even at elevated temperatures. We also found that BOD-GO-A behaves similar to the native protein which could be attributed to the fact that at 
Table 4 Kinetic parameters derived from the thermal inactivation experiment

\begin{tabular}{|c|c|c|c|c|c|c|}
\hline & $\alpha_{1}$ & $K_{1}\left(\min ^{-1}\right)$ & $t_{1 / 2}(\min )$ & $\alpha_{2}$ & $K_{2}\left(\min ^{-1}\right)$ & $\mathrm{t}_{1 / 2}$ (min) \\
\hline BOD & $0.31 \pm 0.02$ & $0.19 \pm 0.03$ & 3.6 & $0.67 \pm 0.01$ & $0.0029 \pm 0.0002$ & 239.0 \\
\hline Dex-BOD & $0.69 \pm 0.01$ & $0.13 \pm 0.02$ & 5.3 & $0.30 \pm 0.02$ & $0.0016 \pm 0.0001$ & 433.2 \\
\hline BOD-GO-A & $0.29 \pm 0.02$ & $0.18 \pm 0.03$ & 3.9 & $0.69 \pm 0.1$ & $0.0035 \pm 0.0002$ & 198.0 \\
\hline BOD-GO-C & $0.33 \pm 0.02$ & $0.20 \pm 0.03$ & 3.5 & $0.65 \pm 0.02$ & $0.0038 \pm 0.0002$ & 182.4 \\
\hline Dex-BOD-GO-C & $0.73 \pm 0.03$ & $0.15 \pm 0.09$ & 4.6 & $0.26 \pm 0.01$ & $0.0016 \pm 0.0002$ & 330.7 \\
\hline
\end{tabular}

higher temperatures a desorption and adsorption equilibrium may be occurring in solution. This could cause the adsorbed protein to lose its catalytic activity faster than the covalently attached protein. The inactivation process of the covalently immobilized protein (BOD-GO-C) may be slower because $\mathrm{GO}$ provides a confinement restricting enzyme's mobility; as a result the enzyme retains the tertiary structure for longer, when compared to BOD-GOA. These results are consistent with the findings of $H / D$ exchange experiments.

\section{Conclusions}

The primary goal of this research was to determine if chemical glycosylation increases the stability of BOD in solution and immobilized on GO nanosheets. We also wanted to determine the mechanism by which glycosylation increases stability and how GO influences the bioconjugates stability. The results obtained demonstrate that chemical glycosylation of BOD induces a decrease in catalytic activity that was unrelated to conformational changes or a loss in binding substrate affinity. By measuring $H / D$ exchange we found that after glycosylation the kinetics of H/D exchange are indeed reduced, confirming that the loss in activity was related to a reduction in protein structural dynamics. A decrease in protein dynamic and an increase in thermostability were observed for the covalent bioconjugate, when compared to BODGO-A. This thermostability improvement is caused by the confinement induced by the close proximity to GO nanosheets and the lack of freedom due to the covalent immobilization of the protein. When we used the chemically glycosylated protein to form the covalent bioconjugates (Dex-BOD-GO-C), we found a decrease in catalytic activity that was produced by the glycosylation and not by the immobilization process, since the specific activity results were similar. A drastic decrease in protein dynamics was found, creating an even higher thermostable bioconjugate. This is a consequence of the confinement produced by the glycans and GO nanosheets. In conclusion, we found that glycosylation helps producing a highly stable protein-GO bioconjugate for bio-nanotechnological applications, by restricting protein mobility and thus increasing stability.

\section{Methods \\ Chemicals}

Bilirubin oxidase $\left(2.60 \mathrm{U} \mathrm{mg}^{-1}\right)$ from Myrothecium $s p$. was donated from Amano Enzyme Inc. (Elgin, IL). Graphite platelet nanofibers $98 \%$ (50-250 nm), 2,2'-azino-bis (3-ethylbenzothiazoline-6-sulphonic acid) (ABTS) $\geq 98 \%$, potassium permanganate $\left(\mathrm{KMnO}_{4}\right)$ $\geq 99 \%$, and $30 \%$ hydrogen peroxide $\left(\mathrm{H}_{2} \mathrm{O}_{2}\right)$ were purchased from Sigma-Aldrich (St. Louis, MO, USA). Sulfuric acid $\left(\mathrm{H}_{2} \mathrm{SO}_{4}\right)\left(\right.$ OPTIMA $\left.^{\mathrm{TM}}\right)$ and sodium phosphate monobasic 99 \% (Acros) were from Thermo Scientific (Fair Lawn, NJ, USA). Dextran hexanoic acid (Dex$\mathrm{COOH}, \mathrm{M}_{\mathrm{w}} 1 \mathrm{kDa}$ ) was purchased from Carbomer (San Diego, CA, USA). 1-Ethyl-3-[3-dimethylaminopropyl] carbodiimide hydrochloride and $N$-hydroxysulfosuccinimide (99\%) were from Proteochem (Denver, CO, USA).

\section{Glycosylation of BOD with dextran}

First, the carboxylic acid group of dextran hexanoic acid was activated with $20 \mathrm{mM}$ of EDC/25 mM of sulfo-NHS in $0.1 \mathrm{M} \mathrm{MES}, 0.5 \mathrm{M} \mathrm{NaCl}$ at $\mathrm{pH} 6.0$ for $30 \mathrm{~min}$ at room temperature. Afterwards, EDC/sulfo-NHS was removed by dialysis $\left(\mathrm{M}_{\mathrm{w}}\right.$ cut-off of $\left.100-500 \mathrm{Da}\right)$ for $3 \mathrm{~h}$ against $0.1 \mathrm{M} \mathrm{MES}, 0.5 \mathrm{M} \mathrm{NaCl}$ at $\mathrm{pH} 6.0$ and then for $2 \mathrm{~h}$ against nanopure water to remove salts, because the intermediated is stable at $\mathrm{pH} 7$ for $4-5 \mathrm{~h}$. Then sulfo-NHS-dextran was frozen in liquid $\mathrm{N}_{2}$ and lyophilized for $48 \mathrm{~h}$. Chemical protein glycosylation of BOD $\left(20 \mathrm{mg} \mathrm{mL}^{-1}\right)$ was achieved by the addition of sulfo-NHS-dextran at a molar ratio of 1:6 (mol protein: mol dextran) in $100 \mathrm{mM}$ PBS, $150 \mathrm{mM}$ $\mathrm{NaCl}$ at $\mathrm{pH} 7.2$ for $3 \mathrm{~h}$. Reaction mixtures were gently stirred at $4{ }^{\circ} \mathrm{C}$ for $3 \mathrm{~h}$ followed by dialysis purification $\left(\mathrm{M}_{\mathrm{w}}\right.$ cut-off $20 \mathrm{kDa}$ ) for $24 \mathrm{~h}$ at $4{ }^{\circ} \mathrm{C}$, flash frozen with liquid $\mathrm{N}_{2}$, and lyophilization. The degree of protein modification was determined by colorimetric titration of unreacted amino groups with 2,4,6-trinitrobenzene sulfonic acid [37].

\section{Preparation of bilirubin oxidase-graphene oxide bioconjugates}

Bilirubin oxidase-graphene oxide bioconjugates (BODGO) were immobilized following two different methodologies: by adsorption and covalently linked. The 
adsorbed bioconjugates were prepared by mixing BOD $\left(0.5 \mathrm{mg} \mathrm{mL}{ }^{-1}\right)$ with $\mathrm{GO}\left(0.1 \mathrm{mg} \mathrm{mL}^{-1}\right)$ at $4{ }^{\circ} \mathrm{C}$ for $30 \mathrm{~min}$. The mixture was then centrifuged at $5000 \mathrm{~g}$ for $15 \mathrm{~min}$ using a centrifugal filtering unit $\left(\mathrm{M}_{\mathrm{w}}\right.$ cutoff $100 \mathrm{kDa}$ ). The supernatant was collected to determine the enzyme loading. The adsorbed bioconjugates (denoted as BOD-GO-A) were rinsed three times with water to remove nonspecifically adsorbed enzyme. Then, they were resuspended in water, frozen in liquid $\mathrm{N}_{2}$, and lyophilized for $48 \mathrm{~h}$. To prepare the covalent biocongugates, denoted as BOD-GO-C for the native and Dex-BOD-GO-C for the glycosylated protein, we first activated the carboxylic groups at the surface of GO. The activation was accomplished by mixing GO $\left(0.1 \mathrm{mg} \mathrm{mL}{ }^{-1}\right)$ with $20 \mathrm{mM}$ of EDC/25 mM of sulfoNHS in $0.1 \mathrm{M}$ MES, $0.5 \mathrm{M} \mathrm{NaCl}$ at pH 6.0 for $30 \mathrm{~min}$ at room temperature. Then, EDC/sulfo-NHS was removed by repeated washing with nanopure water using the centrifugal filtering unit $\left(\mathrm{M}_{\mathrm{w}}\right.$ cut-off $\left.100 \mathrm{kDa}\right)$ until the absorbance $(280 \mathrm{~nm})$ in the supernatant was zero. Sulfo-NHS-GO $\left(0.1 \mathrm{mg} \mathrm{mL}^{-1}\right)$ was dissolved in buffer and mixed with the BOD $\left(0.5 \mathrm{mg} \mathrm{mL}^{-1}\right)$ or Dex-BOD $\left(0.5 \mathrm{mg} \mathrm{mL}^{-1}\right)$ for $3 \mathrm{~h}$ at $4{ }^{\circ} \mathrm{C}$ to obtain the covalent bioconjugate and glyco-bioconjugate. Then, we followed the same purification procedure as described for the adsorbed bioconjugates.

\section{Activity assays}

The specific activity of BOD and the bioconjugates was determined photometrically by monitoring the oxidation reaction of 2,2'-azino-bis(3-ethylbenzthiazoline-6-sulphonic acid) (ABTS) at $340 \mathrm{~nm}\left(\varepsilon 340=3.45 \times 10^{-4} \mathrm{M}^{-1} \mathrm{~cm}^{-1}\right)$ on a Shimadzu $2450 \mathrm{UV} / \mathrm{Vis}$ spectrophotometer. The reactions were carried out in $0.1 \mathrm{M} \mathrm{PBS} \mathrm{pH} 7.4$ and started by the addition of $150 \mu \mathrm{l}$ of enzyme $\left(\left[\mathrm{E}_{0}\right]=30 \mathrm{nM}\right)$ to $100 \mu \mathrm{l}$ of ABTS $\left(\left[\mathrm{S}_{0}\right]=10 \mathrm{mM}\right)$ in a final volume of $1 \mathrm{ml}$ at $25^{\circ} \mathrm{C}$. The kinetic parameters were determined from initial velocities using five substrate concentrations ranging from 1 to $20 \mathrm{mM}$. Lineweaver-Burk plot analysis was used to determine the Michaelis-Menten parameters $K_{m}$ and $k_{\text {cat }}$. For the thermal inactivation experiments, protein samples were incubated at $45^{\circ} \mathrm{C}$ for $2,4,6,8,10,15,20,25,30 \mathrm{~min}$, and then every $30 \mathrm{~min}$ for a period of $6 \mathrm{~h}$. Then, the residual activity was assayed at $25^{\circ} \mathrm{C}$ as described above.

\section{Characterization of GO and BOD-GO bioconjugates}

The X-ray photoelectron spectra (XPS) recorded on a Physical Electronics Quantum 2000 Scanning ESCA Microscope spectrometer with an $\mathrm{Al} \mathrm{K} \mathrm{X-ray} \mathrm{source} \mathrm{at}$ $15 \mathrm{kV}$ and $25 \mathrm{~W}$. The pass energy used was $117.40 \mathrm{eV}$ for the survey analysis and $58.70 \mathrm{eV}$ for the high-resolution energy studies. Binding energies were corrected with respect to the aliphatic hydrocarbon $\mathrm{C} 1 \mathrm{~s}$ signal at
$284.5 \mathrm{eV}$ [48]. Raman spectra were recorded on a Thermo Scientific DXR Raman Microscope with a laser source of $532 \mathrm{~nm}, 20 \mathrm{X}$ objective, and $9 \mathrm{~mW}$ laser power; an average of 120 scans were recorded for each sample. FT-IR spectra were measured on a Nicolet NEXUS 470 infrared spectrophotometer from 400 to $4000 \mathrm{~cm}^{-1}$. Samples were prepared as $\mathrm{KBr}$ pellet. Spectra were recorded in transmission mode at $2 \mathrm{~cm}^{-1}$ and 240 scans were averaged to obtain each spectrum. The XRD spectra were measured on a Rigaku Smart Lab with and $\mathrm{Cu} \mathrm{Ka}$ X-ray source $(\lambda=1.54 \AA)$ and $\mathrm{Kb}$ filter. Zeta-potential values were recorded on a Zetasizer Nanoseries (Malvern).

\section{Circular dichroism (CD) spectroscopy}

CD spectra were acquired with a JASCO J-1500 CD spectrophotometer at $25{ }^{\circ} \mathrm{C}$. BOD, Lyo-BOD, Dex-BOD, and BOD-GO bioconjugates were prepared in $0.1 \mathrm{M}$ PBS $\mathrm{pH}$ 7.4. CD spectra were recorded from 250 to $300 \mathrm{~nm}$ using $10 \mathrm{~mm}$ path length quartz cells for the tertiary structure and from 200 to $260 \mathrm{~nm}$ using $1 \mathrm{~mm}$ path length quartz cells for the secondary structure at a scan rate of $50 \mathrm{~nm} \mathrm{~min}{ }^{-1}$ with a protein concentration of 0.6 and $0.2 \mathrm{mg} \mathrm{mL}^{-1}$, respectively. Each spectrum was obtained by averaging three scans at $1 \mathrm{~nm}$ resolution and solvent reference spectra were digitally subtracted from protein $\mathrm{CD}$ spectra. The changes in the secondary structures of the proteins and bioconjugates, in terms of $\alpha$-helix, $\beta$-sheet, $\beta$-turn, and unordered structure, were calculated from the $\mathrm{CD}$ data using the $\mathrm{CDNN}$ program (version 2.0). Results presented for the changes in the secondary structure are an average of three solutions prepared independently.

\section{Kinetics of hydrogen/deuterium (H/D) exchange}

Amide H/D exchange FTIR spectra were measured on a Nicolet NEXUS 470 infrared spectrophotometer using $\mathrm{CaF}_{2}$ windows and $25 \mu \mathrm{m}$ Teflon spacers. Exchange time was started at the moment of $\mathrm{D}_{2} \mathrm{O}$ addition. Spectra $\left(2000-1300 \mathrm{~cm}^{-1}\right)$ were collected at $2,4,6,8,10$, $15,20,25$, and $30 \mathrm{~min}$, then every $30 \mathrm{~min}$ for a period of $6 \mathrm{~h}$. For the first $30 \mathrm{~min}, 24$ scans were averaged, and after $30 \mathrm{~min}, 60 \mathrm{scans}$, all at $2 \mathrm{~cm}^{-1}$ resolution. Spectra of buffer blanks in $\mathrm{D}_{2} \mathrm{O}$ were subtracted from all sample spectra. Samples were prepared at a concentration of $4 \mathrm{mg} \mathrm{mL}{ }^{-1}$, and $1 \mathrm{~mL}$ was flash frozen with liquid $\mathrm{N}_{2}$ followed by lyophilization. Samples were dissolved in $200 \mu \mathrm{l}$ of $\mathrm{D}_{2} \mathrm{O}$ yielding a final protein concentration in the cell of $40 \mathrm{mg} \mathrm{mL}^{-1}$.

H/D exchange spectra were processed for quantitative analysis in the form of hydrogen exchange decay plots (X vs. time). The fraction $\mathrm{X}$ of unexchanged backbone hydrogen atoms at time $t$ was determined by the following equation: $[7,49]$ 


$$
X=[w(t)-w(\infty)] /[w(0)-w(\infty)]
$$

where $\mathrm{w}(\mathrm{t})$ is the ratio of the baseline corrected absorbance of amide II $\left(1544 \mathrm{~cm}^{-1}\right)$ to amide I $\left(1640 \mathrm{~cm}^{-1}\right)$ at a time $t, \mathrm{w}(0)$ is the amide II/amide I ratio of the undeuterated proteins and $\mathrm{w}(\infty)$ is the amide II/amide I ratio for the fully deuterated proteins. $\mathrm{w}(0)$ was calculated from IR spectra for the undeuterated proteins measured as $\mathrm{KBr}$ pellets and $\mathrm{w}(\infty)$ from samples incubated for 15 days in $\mathrm{D}_{2} \mathrm{O}$ at $37^{\circ} \mathrm{C}$ to ensure complete exchange. The $\mathrm{pH}$ values of the H/D exchange experiments were taken from the direct readings observed on the $\mathrm{pH}$ meter and the $\mathrm{pD}$ values were calculated using the following equation: $\mathrm{pD}=\mathrm{pH}+0.4$ [50]. Experimental $\mathrm{pD}$ values were measured from samples after the addition of $\mathrm{D}_{2} \mathrm{O}$ and were found to be 8.2.

The global Gibbs free-energy of microscopic unfolding $\left(\Delta G^{m i c}\right)$ per mole of peptide was calculated through thermodynamic analysis of the H/D exchange kinetics using the following equation: $[7,50]$

$$
\Delta G^{m i c}=-R T\left(k_{o b s} / k_{0}\right)
$$

where $\mathrm{k}_{\mathrm{obs}}=\mathrm{k}_{\mathrm{HX}, 1}+\mathrm{k}_{\mathrm{HX}, 2}$ known as the measured rate constants, and $\mathrm{k}_{0}$ is the chemical exchange rate constant. The chemical exchange rate constant $\left(\mathrm{k}_{0}\right)$ was calculated as a function of temperature and $\mathrm{pH}$ according to the following equation: [50]

$$
k_{0}=\left(10^{-p H \text { read }}+10^{-p H \text { read }-5}\right) 10^{0.05(T-25)} s^{-1}
$$

\section{Additional file}

Additional file 1. In the Supplemental Material Section the synthesis and characterization of $\mathrm{GO}$ are shown.

\begin{abstract}
Abbreviations
GO: graphene oxide; BOD: bilirubin oxidase; FT-IR: fourier transform infrared spectroscopy; XPS: X-ray photoelectron spectroscopy; CD: circular dichroism; $K_{m}$ : Michaelis-Menten constant; $k_{\text {cat }}$ t turnover number; PEG: polyethylene glycol; NHS-tripod: N-hydroxysuccinimidyl ester tripod; Con A: concanavalin A; GOD: glucose oxidase; HRP: horseradish peroxidase; OxOx: oxalate oxidase; Cyt-c: cytochrome c; BSA: bovine serum albumin; Dex-BOD: glycosylated bilirubin oxidase; Lyo-BOD: Iyophilized bilirubin oxidase; BOD-GO-A: adsorbed bilirubin oxidase on graphene oxide; BOD-GO-C: covalent attached bilirubin oxidase on graphene oxide; Dex-BOD-GO-C: glycosylated bilirubin oxidase covalent attached on graphene oxide; $\Delta G^{\text {mic. }}$ microscopic global free energy; $\left(\Delta \mathrm{G}^{\mathrm{mic}}\right)^{-1}$ : protein mobility
\end{abstract}

\section{Authors' contributions}

GH carried out all the experimental studies, analyzed the data, and wrote the manuscript. DS carried out the synthesis and characterization of the graphene oxide nanosheets. AO participated in the bioconjugates characterization. DG helped DS during the synthesis of graphene oxide. CC is the scientific supervisor of the graphene oxide synthesis. KG is the principal and scientific supervisor of the study. KG and CC have revised the final version of manuscript. All authors read and approved the final manuscript.

\section{Acknowledgements}

This work was supported in part by the Institute for Functional Nanomaterials (NSF Cooperative Agreement 1002410). This work had financial support of NASA-URC Grant Nos. NNX10AQ17A. GH is supported by the fellowship from NIH Research Initiative for Scientific Enhancement (RISE) program grant 2R25GM061151-13. The authors thank the Materials Characterization Center (MCC) at University of Puerto Rico (UPR) for the use of the XPS instrument. The authors also like to thank to the research facilities from the University of Puerto Rico at the Molecular Science Research Building for the use of the XRD, zetapotential, and CD instruments.

\section{Competing interests}

The authors declare they have no competing interests.

Received: 10 August 2015 Accepted: 8 October 2015 Published online: 19 October 2015

\section{References}

1. Pattammattel A, Puglia M, Chakraborty S, Deshapriya IK, Dutta PK, Kumar $\mathrm{CV}$. Tuning the activities and structures of enzymes bound to graphene oxide with a protein glue. Langmuir. 2013;29:15643-54.

2. Zhang Y, Zhang J, Huang X, Zhou X, Wu H, Guo S. Assembly of graphene oxide-enzyme conjugates through hydrophobic interaction. Small. 2012:8:154-9

3. Zhang J, Zhang F, Yang H, Huang X, Liu H, Zhang J, Guo S. Graphene oxide as a matrix for enzyme immobilization. Langmuir. 2010;26:6083-5.

4. Mittag T, Kay LE, Forman-Kay JD. Protein dynamics and conformational disorder in molecular recognition. J Mol Recognit. 2010;23:105-16.

5. Kempner ES. Movable lobes and flexible loops in proteins structural deformations that control biochemical activity. FEBS Lett. 1993;326:4-10

6. Sola RJ, Griebenow K. Influence of modulated structural dynamics on the kinetics of alpha-chymotrypsin catalysis. Insights through chemical glycosylation, molecular dynamics and domain motion analysis. FEBS J. 2006;273:5303-19.

7. Sola RJ, Griebenow K. Chemical glycosylation: new insights on the interrelation between protein structural mobility, thermodynamic stability, and catalysis. FEBS Lett. 2006;580:1685-90.

8. Pagan M, Sola RJ, Griebenow K. On the role of protein structural dynamics in the catalytic activity and thermostability of serine protease subtilisin Carlsberg. Biotechnol Bioeng. 2009;103:77-84.

9. Huang J, Gao X, Jia J, Kim JK, Li Z. Graphene oxide-based amplified fluorescent biosensor for $\mathrm{Hg}(2+)$ detection through hybridization chain reactions. Anal Chem. 2014;86:3209-15.

10. Ambrosi A, Sasaki T, Pumera M. Platelet graphite nanofibers for electrochemical sensing and biosensing: the influence of graphene sheet orientation. Chem Asian J. 2010;5:266-71.

11. Das D, Ghosh S, Basumallick I. Electrochemical studies on glucose oxidation in an enzymatic fuel cell with enzyme immobilized on to reduced graphene Oxide surface. Electroanalysis. 2014;26:2408-18.

12. Sun X, Liu Z, Welsher K, Robinson JT, Goodwin A, Zaric S, Dai H. Nanographene oxide for cellular imaging and drug delivery. Nano Res. 2008;1:203-12.

13. Liu J, Cui L, Losic D. Graphene and graphene oxide as new nanocarriers for drug delivery applications. Acta Biomater. 2013;9:9243-57.

14. Bao H, Pan Y, Ping Y, Sahoo NG, Wu T, Li L, Li J, Gan LH. Chitosan-functionalized graphene oxide as a nanocarrier for drug and gene delivery. Small. 2011;7:1569-78.

15. Shao Y, Wang J, Wu H, Liu J, Aksay IA, Lin Y. Graphene based electrochemical sensors and biosensors: a review. Electroanalysis. 2010;22:1027-36.

16. Shen H, Zhang L, Liu M, Zhang Z. Biomedical applications of graphene. Theranostics. 2012;2:283-94.

17. Wang Y, Li Z, Wang J, Li J, Lin Y. Graphene and graphene oxide: biofunctionalization and applications in biotechnology. Trends Biotechnol. 2011;29:205-12.

18. Jin L, Yang K, Yao K, Zhang S, Tao H, Lee ST, Liu Z, Peng R. Functionalized graphene oxide in enzyme engineering: a selective modulator for enzyme activity and thermostability. ACS Nano. 2012;6:4864-75.

19. Alava T, Mann JA, Theodore C, Benitez JJ, Dichtel WR, Parpia JM, Craighead HG. Control of the graphene-protein interface is required to preserve adsorbed protein function. Anal Chem. 2013;85:2754-9. 
20. Zhou L, Jiang Y, Gao J, Zhao X, Ma L, Zhou Q. Oriented immobilization of glucose oxidase on graphene oxide. Biochem Eng J. 2012;69:28-31.

21. Delgado Y, Morales-Cruz M, Hernandez-Roman J, Martinez Y, Griebenow K. Chemical glycosylation of cytochrome c improves physical and chemical protein stability. BMC Biochem. 2014;15:16.

22. Hernandez-Cancel G, Suazo-Davila D, Medina-Guzman J, Rosado-Gonzalez M, Diaz-Vazquez LM, Griebenow K. Chemically glycosylation improves the stability of an amperometric horseradish peroxidase biosensor. Anal Chim Acta. 2015:854:129-39.

23. Mendez J, Morales Cruz M, Delgado Y, Figueroa CM, Orellano EA, Morales M, Monteagudo A, Griebenow K. Delivery of chemically glycosylated cytochrome $\mathrm{c}$ immobilized in mesoporous silica nanoparticles induces apoptosis in HeLa cancer cells. Mol Pharm. 2014;11:102-11.

24. Flores-Fernandez GM, Griebenow K. Glycosylation improves alphachymotrypsin stability upon encapsulation in poly(lactic-co-glycolic)acid microspheres. Results Pharma Sci. 2012;2:46-51.

25. Huang J, Guerrero A, Parker E, Strum JS, Smilowitz JT, German JB, Lebrilla CB. Site-specific glycosylation of secretory immunoglobulin A from human colostrum. J Proteome Res. 2015;14:1335-49.

26. Wormald MR, Rudd PM, Harvey DJ, Chang SC, Scragg IG, Dwek RA. Variations in oligosaccharide-protein interactions in immunoglobulin $\mathrm{G}$ determine the site-specific glycosylation profiles and modulate the dynamic motion of the Fc oligosaccharides. Biochemistry. 1997;36:1370-80.

27. Shao $Q$, Wu $P, X u X$, Zhang $H$, Cai C. Insight into the effects of graphene oxide sheets on the conformation and activity of glucose oxidase: towards developing a nanomaterial-based protein conformation assay. Phys Chem Chem Phys. 2012;14:9076-85.

28. Yao YD, Sun TM, Huang SY, Dou S, Lin L, Chen JN, Ruan JB, Mao CQ, Yu FY, Zeng MS, Zang JY, et al. Targeted delivery of PLK1-siRNA by ScFV suppresses Her2+ breast cancer growth and metastasis. Sci Transl Med. 2012:4:130ra48.

29. Batra B, Lata S, Sunny, Rana JS, Pundir CS. Construction of an amperometric bilirubin biosensor based on covalent immobilization of bilirubin oxidase onto zirconia coated silica nanoparticles/chitosan hybrid film. Biosens Bioelectron. 2013:44:64-9.

30. Kannan P, Chen H, Lee VT, Kim DH. Highly sensitive amperometric detection of bilirubin using enzyme and gold nanoparticles on sol-gel film modified electrode. Talanta. 2011;86:400-7.

31. Omar Garcia S, Narváez Villarrubia C, Falase A, Atanassov P. Gas-diffusion cathodes integrating carbon nanotube modified-Toray paper and bilirubin oxidase. J Electrochem Soc. 2014;161:H523-8.

32. Kim J, Parkey J, Rhodes C, Gonzalez-Martin A. Development of a biofuel cell using glucose-oxidase- and bilirubin-oxidase-based electrodes. J Solid State Electrochem. 2009;13:1043-50.

33. Dos Santos L, Climent V, Blanford CF, Armstrong FA. Mechanistic studies of the 'blue' Cu enzyme, bilirubin oxidase, as a highly efficient electrocatalyst for the oxygen reduction reaction. Phys Chem Chem Phys. 2010;12:13962-74.

34. Mano N. Features and applications of bilirubin oxidases. Appl Microbiol Biotechnol. 2012;96:301-7.
35. Mano N, Edembe L. Bilirubin oxidases in bioelectrochemistry: features and recent findings. Biosens Bioelectron. 2013;50:478-85.

36. Samejima T, Wu CS, Shiboya K, Kaji H, Koikeda S, Ando K, Yang JT. Conformation of bilirubin oxidase in native and denatured states. J Protein Chem. 1994;13:307-13.

37. Habeeb AF. Determination of free amino groups in proteins by trinitrobenzenesulfonic acid. Anal Biochem. 1966;14:328-36.

38. Arakawa T, Prestrelski SJ, Kenney WC, Carpenter JF. Factors affecting short-term and long-term stabilities of proteins. Adv Drug Deliv Rev. 2001;46:307-26.

39. Henzler-Wildman KA, Lei M, Thai V, Kerns SJ, Karplus M, Kern D. A hierarchy of timescales in protein dynamics is linked to enzyme catalysis. Nature. 2007;450:913-6.

40. Gotoh Y, Kondo Y, Kaji H, Takeda A, Samejima T. Characterization of copper atoms in bilirubin oxidase by spectroscopic analyses. J Biochem. 1989;106:621-6.

41. Jackson M, Mantsch HH. The use and misuse of FTIR spectroscopy in the determination of protein structure. Crit Rev Biochem Mol Biol. 1995;30:95-120.

42. Ferraro DM, Lazo N, Robertson AD. EX1 hydrogen exchange and protein folding. Biochemistry. 2004;43:587-94.

43. Castillo B, Sola RJ, Ferrer A, Barletta G, Griebenow K. Effect of PEG modification on subtilisin Carlsberg activity, enantioselectivity, and structural dynamics in 1,4-dioxane. Biotechnol Bioeng. 2008;99:9-17.

44. Shental-Bechor D, Levy Y. Communication: folding of glycosylated proteins under confinement. J Chem Phys. 2011;135:141104.

45. England J, Lucent D, Pande V. Rattling the cage: computational models of chaperonin-mediated protein folding. Curr Opin Struct Biol. 2008;18:163-9.

46. Klimov DK, Newfield D, Thirumalai D. Simulations of $\beta$-hairpin folding confined to spherical pores using distributed computing. Proc Natl Acad Sci. 2002;99:8019-24.

47. Sola RJ, Rodriquez-Martinez JA, Griebenow K. Modulation of protein biophysical properties by chemical glycosylation: biochemical insights and biomedical implications. Cell Mol Life Sci. 2007:64:2133-52.

48. Cunci L, Velez CA, Perez I, Suleiman A, Larios E, Jose-Yacaman M, Watkins $\mathrm{J}$, Cabrera CR. Platinum electrodeposition at unsupported electrochemically reduced nanographene oxide for enhanced ammonia oxidation. ACS Appl Mater Interfaces. 2014;6:2137-45.

49. Rodriguez-Martinez JA, Sola RJ, Castillo B, Cintron-Colon HR, Rivera-Rivera I, Barletta G, Griebenow K. Stabilization of alpha-chymotrypsin upon PEGylation correlates with reduced structural dynamics. Biotechnol Bioeng. 2008;101:1142-9.

50. Zavodszky P, Johansen JT, Hvidt A. Hydrogen-exchange study of the conformational stability of human carbonic-anhydrase B and its metallocomplexes. Eur J Biochem. 1975;56:67-72.

\section{Submit your next manuscript to BioMed Central and take full advantage of:}

- Convenient online submission

- Thorough peer review

- No space constraints or color figure charges

- Immediate publication on acceptance

- Inclusion in PubMed, CAS, Scopus and Google Scholar

- Research which is freely available for redistribution

Submit your manuscript at 